2014, volume 3, issue 1

Raulinajtys-Grzybek M., Świderska G. K.. (2014). Object-based costing as an important tool for the economic analysis of sustainable development. Copernican Journal of Finance \& Accounting, 3(1), 135-144. http://dx.doi.org/10.12775/CJFA.2014.011

\author{
Monika Raulinajtys-Grzybek*, Gertruda Krystyna Świderska \\ Warsaw School of Economics
}

\title{
OBJECT-BASED COSTING AS AN IMPORTANT TOOL FOR THE ECONOMIC ANALYSIS OF SUSTAINABLE DEVELOPMENT
}

Keywords: object-based costing, accounting for sustainable development, healthcare.

\section{J E L Classification: I15.}

Abstract: The purpose of the article was to verify whether the object-based costing provides information about the costs and benefits that arise in the enterprise as a result of activities related to environmental and socio-economic factors. The constructive approach method was used for this purpose. The object-based costing model for healthcare providers has been designed and subjected to empirical verification. The critical analysis proved its usefulness for economic evaluation of sustainable development. The obtained results demonstrate its utility and applicability.

\section{OBIEKTOWY RACHUNEK KOSZTÓW JAKO ISTOTNY ELEMENT EKONOMICZNYCH ASPEKTÓW ZRÓWNOWAŻONEGO ROZWOJU}

Słowa kluczowe: obiektowy rachunek kosztów, rachunkowość w teorii zrównoważonego rozwoju, opieka zdrowotna.

Klasyfikacja J E L: I15.

Abstrakt: Celem artykułu była weryfikacja, czy obiektowy rachunek kosztów pozwala na dostarczenie informacji o kosztach i korzyściach jakie powstają w przedsiębiorstwie

Date of submission: February 27, 2014; date of acceptance: March 21, 2014.

* Contact information:mrauli@sgh.waw.pl, Warsaw School of Economics, Al. Niepodległości 162, 02-554 Warszawa, Poland, phone: 601644325. 
w wyniku działań związanych z czynnikami ekologicznymi i społeczno-ekonomicznymi. W tym celu zastosowano metodę podejścia konstruktywnego. Zaprojektowano i poddano empirycznej weryfikacji model obiektowego rachunku kosztów dla podmiotów leczniczych. W ramach analizy krytycznej oceniono jego użyteczność dla ekonomicznej oceny zrównoważonego rozwoju. Otrzymane wyniki wskazują na uży teczność i możliwość wdrożenia tego rozwiązania.

Translated by Monika Raulinajtys-Grzybek

\section{IIINTRODUCTION}

The problem of ensuring sustainable development can be considered from both macro- and microeconomic perspective. At the macroeconomic level, it relates primarily to formulate policies to ensure inclusion of the principles of sustainable development and social justice in the socio-economic system (Herath 2005, 1038).

The consequence of the implementation of sustainable development rules at the macro level is the need to develop appropriate metrics and reporting methods at the micro level that will allow for verifying compliance with the operating rules. As indicated by research conducted by Feltmate $(1997,12)$, the need to ensure compliance with regulations is the most common cause of implementing the sustainable development principles in enterprises.

The need to act in accordance with the rules is not the only reason for businesses undertaking actions to implement the sustainable development principles. Birkin and Woodward $(1997,24)$ found that these companies can more effectively meet the consumer needs for sustainable activities and reap the profits from that and further sustainability challenges industry to reduce resource consumption and thereby lower costs.

These causes make the aspects related to the measurement of costs and benefits of economic, social and environmental impact of corporate activities increasingly important for companies and affect the shape of the tools used in accounting.

Traditional accounting tools, governed by the relevant legislation, do not take into account all costs incurred in the manufacture of a product or providing a service. For example, the social costs and certain environmental costs are omitted. Generally it can be assumed, that the traditional tools of accounting do not allow for presenting the effects of externalities arising as a result of the company's activities (Birkin 1997). 
The literature proposes an alternative approach to accounting. Depending on the source, several terms are used to determine them: total cost accounting (Carlsson 2010), accounting for externalities (Ball, Färe, Grosskopf, Zaim 2005), environmental accounting (although this term ignores the socio-economic aspects of sustainable development) (Herath 2005) and accounting for sustainable development (Feltmate 1997). All these terms describe accounting system that includes costs and benefits of internal and external effects of business activities related to environmental, economic and social factors.

Assumptions of sustainable development translate into a number of requirements relating to management accounting and cost accounting, such as (Stappen 2008; Birkin, Woodward 1997a):

- the possibility of a coherent analysis of information covering several periods, such as the design, implementation and withdrawal phases,

- taking a starting point the social needs and the demand for company's products and not maximization of its potential,

- taking into account the quality costs and the costs of externalities,

- the ability to analyse the cost of resources, including natural resources,

- the ability to estimate the total cost of a specific target group - for example, a group of socially excluded.

Examples of tools that can support the implementation of some of these assumptions include e.g. life-cycle costing.

Maunders and Burritt (1991) pointed out that from the point of view of efficiency of enterprise information system it is necessary to select such tools that will be providing information to all stakeholders. It is therefore important that the tools used for reporting information about the costs and benefits of externalities associated with environmental and socio-economic factors were also useful for other purposes, such as financial reporting and internal reports for management. In the area of costing systems activity-based costing seems to be such a tool.

\section{THE RESEARCH METHODOLOGY}

\section{AND THE COURSE OF THE RESEARCH PROCESS}

The results of the study were obtained in a research project using the constructive research approach (Kasanen, Lukka, Siitonen 1993; Labro, Tuomela 2003). The research work included the creation of a cost model for healthcare providers corresponding to the needs of managers and owners, as well as the 
needs of external reporting - including e.g. the need to regulate the healthcare system ${ }^{1}$.

The concept of object-based costing has been proposed. Its flexibility and multidimensionality has previously been tested in several companies operating in other industries (Świderska, Pielaszek 2001; Rybarczyk, Borowski, Świderska 2006).

Object-oriented paradigm is based on the adoption of the "object" as an autonomous unit, representing the item from the real world, which contains all the information necessary to comply with the assigned scope of functionality. Object-oriented analysis and object-oriented programming use objects as essential elements of the decomposition of the problem (Coad, Yourdon 1990; Coad, Yourdon 1991; Martin 1993; Yourdon, Argila 2000).

The following postulated features of object-oriented cost accounting can be distinguished:

- reflection of the elements constituting the reality, which are subject to the management activities, and the relationships between these elements,

- flexibility allowing for multivariate analysis,

- adaptability which means continuous improvements and modifications to answer changes in the environment and managers' needs.

The model developed in the Department of Managerial Accounting of Warsaw School of Economics (Świderska, Rybarczyk, Pielaszek 2002; Świderska 2004; Świderska, Raulinajtys 2009) has been adapted to the specifics of healthcare during workshops on cost accounting and subjected to empirical verification during workshops on external reporting organized for representatives of healthcare providers. The concept of object-oriented approach was used in 39 hospitals to assign costs to the defined objects related to the selected health specialties - gynecology, urology and pulmonology. We used specially prepared spreadsheets for this purpose. The obtained results demonstrate the utility and applicability of this solution.

The model was analysed for the ability to meet the demands arising from the assumptions of the sustainable development concept. The study hypothesis is: An object-based costing allows users to provide information about the costs

${ }^{1}$ During a project "Modern management in healthcare institutions - training in cost accounting and management information and tools of restructuring and consolidation of healthcare institutions" held by Polish Ministry of Health and the Warsaw School of Economics. 
and benefits that arise in the enterprise as a result of the actions related to environmental and socio-economic factors.

\section{THE OUTCOME OF THE RESEARCH PROCESS AND CONCLUSIONS}

The costing systems which allows for the object-oriented approach is activity based costing. It is the best described costing tool which is based on the modelling of processes (activities) in the organization, assigning the resources consumed in these processes and defining parties for the processes are performed and resources consumed (such as products, customers, providers, etc.). Procedures for assessing, grouping and transitioning costs relate directly to real concepts from the physical world in which the organization operates. Potential opportunities and benefits resulting from the application of the object-oriented principles encouraged to explore new conceptual framework of cost accounting.

An example of the application of the object-oriented principles is a modern cost accounting system for healthcare providers. Scheme 1 shows a sample scheme of objects identified for the calculation of the cost of a single health service.

Scheme 1. Object-based costing system for healthcare providers

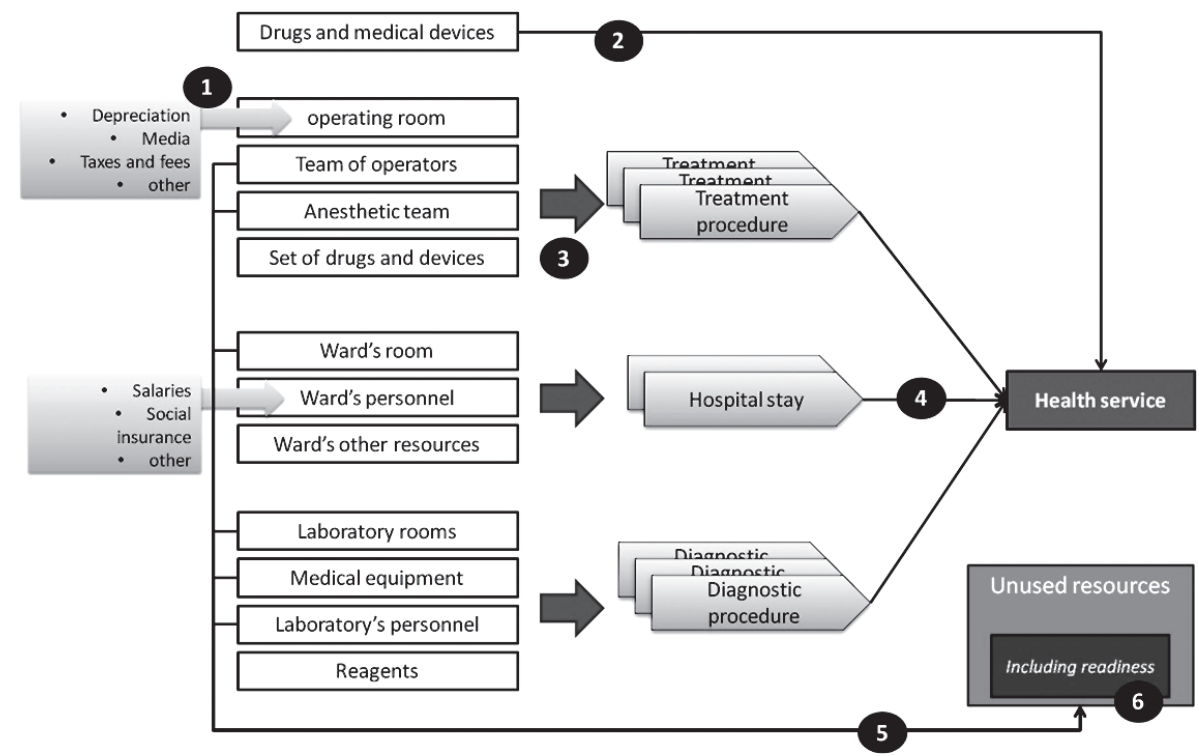

S ou r ce: own. 
The basic idea of object-oriented costing system is the identification of mutually related objects. The model for healthcare providers identifies the following objects:

- economic resources, such as medical equipment or doctors,

- activities, which are primarily medical procedures and activities related to the patient's stay in the ward and medical care provided there,

- final objects, such as health services provided to patients,

- ancillary objects, which include unused potential or readiness ${ }^{2}$ - being the part of it.

The difference between object-based and classic approach lies primarily in the fact that resources and activities are treated as equival (in relation to the final objects) objects for which information is collected and processed. It is particularly important from the point of view of using this tool for providing information related to the issues of sustainable development.

It is possible to extract an additional object on the resource level associated, for example, with natural resources and gather information about its costs. For example, the healthcare industry is consuming large amounts of water (Faezipour, Ferreira 2012). The creation of such an object and tracking its relations with other objects in the model will not only answer the question, what are the costs associated with water use, but also - in which activities it is most commonly consumed.

Object-oriented approach to activity based costing allows for creation of flexible objects that are any combination of the cost of other objects, without the need to preserve the formal hierarchy of these objects. The basis of the relation between objects is perceived causal stream of costs, such as the fact that certain health service a specific set of medical procedures, hospitalization for the appropriate number of days and the use of particular medications.

The basic procedure for cost assignment in this model is presented below:

1. Costs are assigned to the resources according to the causal relationship.

2. Resources can be added directly to the cost of a service (for example, drugs prescribed) or settled on the activities in which they were involved.

3. Assigning resources to activities is carried out on the basis of a standard consumption of resources.

${ }^{2}$ Readiness means this part of the unused potential which maintenance is associated with the need to ensure the continued availability of some medical services. 
4. Activities are assigned to a specific health service in the real amounts stemming from a medical documentation of a service.

5. This part of the involved resources, which was not settled on activities, is the cost of unused resources.

6. The readiness costs are distinguished from the pool of unused resources. The basic features of this approach include the ability to collect data about each of the defined objects and maintain information about relations between resources, activities and final objects. Additionally, the use of standard values for assigning resource costs to activities causes that the model can successfully be used to calculate the planned costs of resources, activities and final objects as well as to estimate the demand for resources and activities reported by defined health services. Two approaches to costing, referred to in the literature as push and pull are shown in Scheme 2 (Cokins 1996, 96-102; Horvath\&Partners 2007, 128-130).

Scheme 2. Scheme of calculation and planning costs in the activity-based costing system
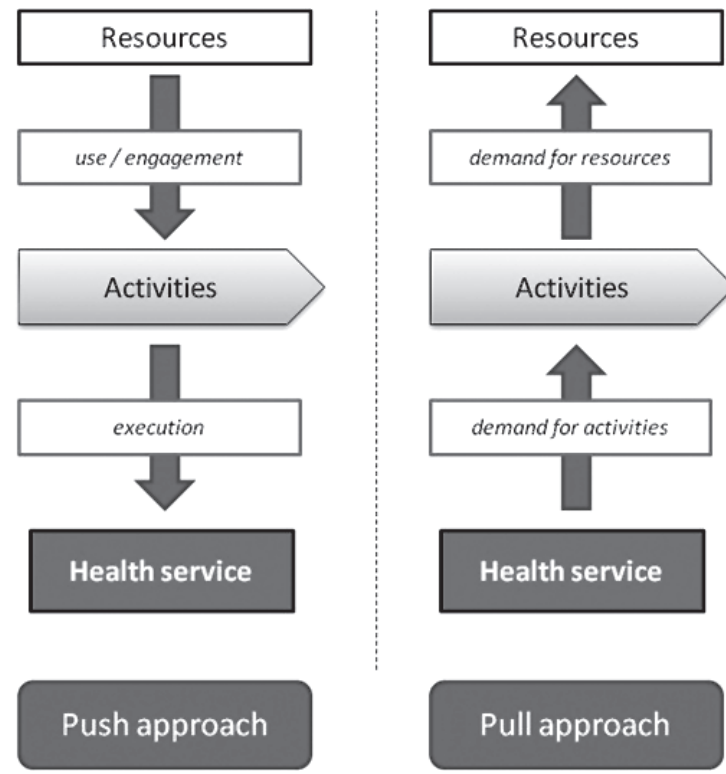

S ou r c e: own.

\section{Push approach}

Pull approach

The pull approach provides an extremely valuable information about, for example, what is the cost of realisation of the social needs resulting from the 
assumptions of sustainable development. It does not take the total potential of the company as the starting point, only a single health service provided in a response to a specific social need. For example, if a strategy for sustainable development presupposes an access to preventive mammography for all women over 50 years of age, the knowledge of population size and costs and amounts of resources consumed in this procedure allows to estimate the financial impact of such a strategy.

An important feature of object-oriented approach is to define a set of attributes for each object Attributes are characteristics that describe an object. Properly constructed dictionaries of attributes allow for limitation of the number of objects in the model while maintaining its high informative value. An exemplary attribute of the final object may be the main diagnosis, age and sex of the patient. Determination of the attribute value for each of the health services will, for example, allow to obtain information about the costs of treating a specific disease among children or the elderly. This feature is particularly useful in determining the cost of providing medical care to groups covered by special protection under the strategy of minimizing social inequalities.

Attributes also allow for defining objects that go beyond the data from the accounting system. For example, the provider's commitment to medical care bears certain costs, but also generates positive externalities associated with the provision of safety for the entire population and securing all other providers who make use of its readiness. If such information was considered valuable for reporting data on realisation of social needs, it would be possible to define such an object in the system.

Coherent dictionary of objects allows for the analysis of cross-sectional information regarding several periods. For example, analysis of project costs for the implementation of new methods for healthcare provision may include research, implementation, provision and ending phase of the project. The exemplary structure of objects included in this analysis is shown in Scheme 3.

Flexible approach to defining objects means that it is possible to recognize a variety of aspects related to the business. For example, collecting information on the costs of activities related to accreditation, training or obtaining ISO certification makes it possible to estimate the cost of the so-called high quality. On the other hand, analysis of the costs of medical complications or costs of these health care services which attributes indicate a failure of the therapeutic process (e.g. fatal patients) makes it possible to determine the cost of low quality. 
Scheme 3. The life cycle of the project in object-based cost accounting
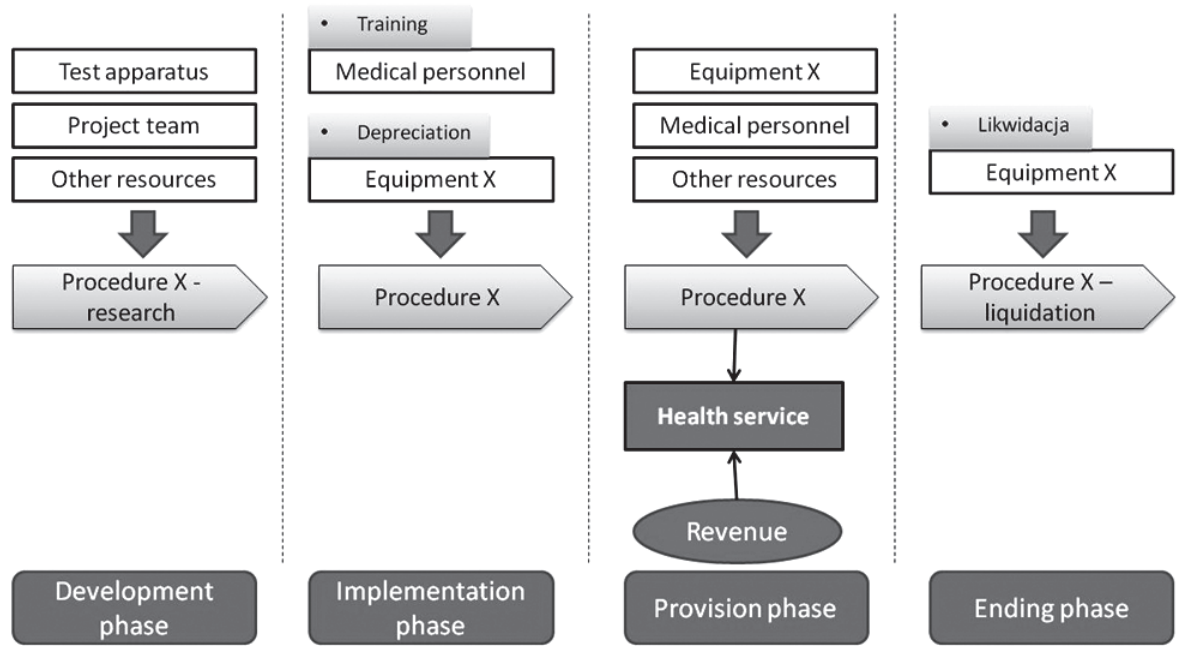

S o u r c : own.

Concluding, creation and implementation of assumptions of sustainable development requires access to cost information, which go far beyond reporting purposes and are complementary to the management needs. Object-based costing allows the fulfillment of objectives related to sustainable development while being a useful tool for other information areas in the enterprise.

The object-based costing system is characterized by high flexibility and multidimensionality and allows for defining any number of freely associated objects, as well as the collection and analysis of information about them. Treating resources and activities equally to final cost objects and maintaining information about relations between objects causes that it can be a valuable tool to provide data on the economic effects of actions relating to environmental and social factors.

\section{REFERENCES}

Ball E., Färe R., Grosskopf S., Zaim O. (2005). Accounting for externalities in the measurement of productivity growth: the Malmquist cost productivity measure. Structural change and economic dynamics, 16(3), 374-394. http://dx.doi.org/10.1016/j. strueco.2004.04.008.

Birkin F. (1997). Management accounting for sustainable development: Part 4: The ecobalance account. Management Accounting, 75(9), 50-52. 
Birkin F., Woodward D. (1997), Management accounting for sustainable development: Part 1: Introduction. Management Accounting, 75(6), 24-26.

Birkin F., Woodward D. (1997a). Accounting for the sustainable corporation. Environmental Management and Health, 8(2), 67-72. http://dx.doi.org/10.1108/095 66169710166557.

Carlsson B. (2010). Total Cost as Suitable Indicator in Realization of More Sustainable Product Life Cycles Regarding Utilization of Natural Abiotic Resources. Journal of Sustainable Development, 3(3), 36-59.

Coad P., Yourdon E. (1990), Object-oriented analysis, 2nd ed., Prentice-Hall, Englewood Cliffs.

Coad P., Yourdon E. (1991), Object-oriented design, Prentice-Hall, Englewood Cliffs.

Faezipour M., Ferreira S. (2012), A System Dynamics Approach to Water Sustainability in Healthcare, http://www.highbeam.com/doc/1P3-2813506701.html (accessed: 29.01.2014).

Feltmate B. (1997). Making sustainable development a corporate reality. CMA, 71(2), 9-16.

Herath G. (2005). Sustainable development and environmental accounting: the challenge to the economics and accounting profession. International Journal of Social Economics, 32(12), 1035-1050. http://dx.doi.org/10.1108/03068290510630999.

Kasanen E., Lukka K., Siitonen A. (1993). The constructive approach in management accounting research. Journal of Management Accounting Research, 5, 243-264.

Labro E., Tuomela T. (2003). On bringing more action into management accounting research: process considerations based on two constructive case studies. European Accounting Review, 12(3), 409-42. http://dx.doi.org/10.1080/0963818032000083559.

Martin J. (1993), Principles of object-oriented analysis and design, Prentice-Hall, Englewood Cliffs.

Maunders K.T., Burritt R.L. (1991). Accounting and ecological crisis. Accounting. Auditing and Accountability, 4(3), 9-26. http://dx.doi.org/10.1108/09513579110003277.

Rybarczyk K., Borowski S., Świderska G.K. (2006), An Object-Oriented Approach to Designing Activity-Based Information Systems, 29th Annual Congress of the European Accounting Association, Dublin, March 22-24.

Stappen R.K. (2008), A Sustainable World is Possible Problemlösungen für das 21. Jahrhundert mit dem Wise-Consensus Verfahren, www.faape.org/wise-consensus-4-2008.pdf (accessed: 29.01.2014).

Świderska G.K. (ed.) (2004), Obiektowy rachunek kosztów działań - koncepcja i wykorzystanie, Monografie i Opracowania, 526, SGH, Warszawa.

Świderska G.K., Pielaszek M. (2001), Wdrożenie koncepcji Rachunku Kosztów Działań (Activity Based Costing) w przedsiębiorstwie z branży farmaceutycznej, Akademia Ekonomiczna w Krakowie Zjazd Katedr Rachunkowości, Kraków.

Świderska G.K., Raulinajtys M. (2009). Rachunek kosztów działań jako podstawa wyceny usług. Zeszyty Teoretyczne Rachunkowości, 49(105), 255-267.

Świderska G.K., Rybarczyk K., Pielaszek M. (2002). Obiektowy rachunek kosztów. Zeszyty Teoretyczne Rachunkowości. 8(64), 223-228.

Yourdon E., Argila C. (2000), Analiza obiektowa i projektowanie: przykłady zastosowań, Wydawnictwa Naukowo-Techniczne, Warszawa. 